\title{
THE DANISH MODEL OF ORGANIC AGRICULTURE
}

\author{
0. Clausen, Ministry of Environment and Food of Denmark \\ Danish Veterinary and Food Administration \\ L. Patryeva, Doctor of Agricultural Sciences, Professor \\ ORCID ID: 0000-0002-4242-0519 \\ Researcher ID: D-1378-2018 \\ Mykolayiv National Agrarian University
}

The article discusses the main elements of the Danish model of organic agriculture, reveals the reasons for Denmark's choice of such a development path, shows the successes of farms that are based on organic production, demonstrates the relevance of the transition of all agriculture to organic production, as one of the bioetic components of the development of society in modern world and the implementation of large-scale shifts in the consciousness and actions of people around the world.

Keywords: organic agriculture, Danish model, regulations, control.

Introduction. Organic agriculture is a holistic production management system that promotes and improves the health of the agroecosystem, and in particular biodiversity, biological cycles, and soil biological activity. It emphasizes the use of management practices in preference to them, to the use of inputs external to the farm, bearing in mind that regional conditions will require locally adapted systems. This is achieved by using, whenever possible, cultural, biological and mechanical methods, as opposed to the use of synthetic materials, to fulfill each function specific within the system (Codex Alimentarius Commission, 1999) [1].

The definition of organic agriculture was proposed by the IFOAM (International Federation of Organic Agriculture Movements) General Assembly in Australia, 1985 - «Organic Agriculture is a production system that sustains the health of soils, ecosystems, and people. It relies on ecological processes, biodiversity and cycles adapted to local conditions, rather than the use of inputs with adverse effects. Organic Agriculture combines tradition, innovation, and science to benefit the shared environment and promote fair relationships and good quality of life for all involved» [2].

As emphasized and interpreted by IFOAM, Organic Agriculture is based on 4 principles: health, ecology, fairness, care [3] :

«Principle of HEALTH. Organic Agriculture should sustain and enhance the health of soil, plant, animal, human and planet as one and indivisible. Health is the wholeness and integrity of living systems. It is the maintenance of physical, mental, social and ecological well-being. Immunity, resilience and regeneration are key characteristics of health. The role of organic agriculture, whether in farming, processing, distribution, or consumption, is to sustain and enhance the health of ecosystems and organisms from the smallest in the soil to human beings. In particular, organic agriculture is intended to produce high quality, nutritious food that contributes to preventive health care and well-being. In view of this it should avoid the use of fertilizers, pesticides, animal drugs and food additives that may have adverse health effects.

Principle of ECOLOGY. Organic Agriculture should be based on living ecological systems and cycles, work with them, emulate them and help sustain them. This principle roots organic agriculture within living ecological systems. It states that production is to be based on ecological processes, and recycling. Nourishment and well-being are achieved through the ecology of the specific production environment. For example, in the case of crops this is the living soil; for animals it is the farm ecosystem; for fish and marine organisms, the aquatic environment. Organic farming, pastoral and wild harvest systems should fit the cycles and ecological balances in nature. These cycles are universal but their operation is site-specific. Organic management must be adapted to local conditions, ecology, culture and scale. Inputs should be reduced by reuse, recycling and efficient management of materials and energy in order to maintain and improve environmental quality and conserve resources. Organic agriculture should attain ecological balance through the design of farming systems, establishment of habitats and maintenance of genetic and

(C) Clausen O., Patryeva L., 2021 
agricultural diversity. Those who produce, process, trade, or consume organic products should protect and benefit the common environment including landscapes, climate, habitats, biodiversity, air and water.

Principle of FAIRNESS. Organic Agriculture should build on relationships that ensure fairness with regard to the common environment and life opportunities. Fairness is characterized by equity, respect, justice and stewardship of the shared world, both among people and in their relations to other living beings. This principle emphasizes that those involved in organic agriculture should conduct human relationships in a manner that ensures fairness at all levels and to all parties - farmers, workers, processors, distributors, traders and consumers. Organic agriculture should provide everyone involved with a good quality of life, and contribute to food sovereignty and reduction of poverty. It aims to produce a sufficient supply of good quality food and other products. This principle insists that animals should be provided with the conditions and opportunities of life that accord with their physiology, natural behavior and well-being. Natural and environmental resources that are used for production and consumption should be managed in a way that is socially and ecologically just and should be held in trust for future generations. Fairness requires systems of production, distribution and trade that are open and equitable and account for real environmental and social costs.

Principle of CARE. Organic Agriculture should be managed in a precautionary and responsible manner to protect the health and well-being of current and future generations and the environment. Organic agriculture is a living and dynamic system that responds to internal and external demands and conditions. The new technologies need to be assessed and existing methods reviewed.. Science is necessary to ensure that organic agriculture is healthy, safe and ecologically sound. Organic agriculture should prevent significant risks by adopting appropriate technologies and rejecting unpredictable ones, such as genetic engineering. Decisions should reflect the values and needs of all who might be affected, through transparent and participatory processes».

Currently, 179 countries of the world are developing organic agriculture, more than 2 million producers are employed in it, 89 countries have their own laws in the field of production and circulation of organic products. The annual production growth is $12-15 \%$ and, according to forecasts, such rates will remain until 2025.

In 2018, the global organic market expanded to $€$ 90 billion. Among the largest markets, experts point out the United States (40 billion euros), Germany (10 billion euros), France (7.9 billion euros) and China (7.6 billion euros) [4].

Among all countries engaged in organic farming, Denmark is of particular importance. Her experience in this matter is invaluable; therefore it is necessary to consider the Danish model of organic development.

Materials and methods. The study was conducted on the basis of open access materials of Internet resources on the Danish model of the organic way. Methods of analysis, synthesis and generalization are used.

Results. Denmark was the first country in the world to introduce rules for organic production, to develop national organic standards and to launch an organic label. Denmark was also the first country in the world to introduce a target for 60 per cent organic products in public sector kitchens.

Denmark has the highest market share of organic food and beverages in the world. In 2017, the organic market share reached about $13.3 \%$. Per capita consumption of organic food was DKK 2,500 in 2017 $\sim$ EUR 335. Organic sales have grown every year in the past decade. Growth rate in retail was $14 \%$ in 2017. 93\% of all Danes occasionally buy organic products. 51.4\% of all Danes bought organic food every single week in 2017.

In 2019, sales of organic food in Danish stores increased by $9 \%$ and accounted for $11.5 \%$ of total sales. The first place in the shopping list belongs to such products - organic milk, grains, flour and vegetables, but other product categories also account for a significant increase and indicate that organic food has become mainstream for most Danes.

Denmark's rapid growth in exports of organic products to EUR 400 million over the last 5 years has been ensured by a high level of food safety, healthy quality food and a unique organic control system.

Danish companies export to near markets such as Germany, Sweden and France and to distant markets in Asia, the Middle East and US. The three largest export markets in 2017 were Germany, Sweden and China respectively. Denmark has many livestock production companies - large and small - that are committed to organic production and to export. It is therefore not surprising that the largest export products are dairy products - fresh milk, cheese, butter and powdered milk - and pork. Danish companies are also well positioned to supply eggs and poultry as well as vegetable products such as feedstuffs, vegetables, groceries and drinks.

The fine reputation of organic products is based on the success of Denmark's agricultural sector, which has turned Denmark into a recognized and respected food nation that supplies high quality food to global consumers: food that is known for its high standards 
of food safety, traceability, quality and sustainability. Collaboration underpins the success of organic production. Collaboration that has involved all actors across the entire value chain for more than 30 years farmers, companies, organizations, official bodies, advisers, politicians, the retail sector, food service and consumers. They have all helped to develop a market-driven organic sector - a type of production that takes account of the environment, nature, animal welfare and sustainability as demanded by many modern consumers.

How and why organic food has become one of the Danish food cluster's strengths in a world that is increasingly demanding sustainable food products?

Organic food is produced according to organic rules - all the way from farm to fork - and contributes to animal welfare, the environment and nature.

Organic production is an overall system of farm management and food production that combines best environmental practices, focus on preservation of natural resources, a high level of biodiversity and application of high animal welfare standards. Organic production is based on four principles: ecology, health, fairness and care. They have been formulated by the International Organic Organization, IFOAM, and provide the basis for organic producers and their way of thinking and acting. They also form the basis of the laws and rules regulating organic production. Before products can be sold as organic, organic farms have to go through a conversion period after starting organic plant and/or livestock production. The conversion period takes two years. During this transition period produce from the farm cannot be sold or labelled as organic [5].

Organic farmers work to preserve the natural environment, including soil fertility, water resources and biodiversity.

The most important agricultural principles are:

- Careful monitoring of the soil's fertility, what farmers put in and take out of the soil, and how their activities affect its composition.

- Adopting a wide and varied crop rotation to break weed and pest cycles and to allow soil recovery time while supplying useful nutrients.

- Nutrients are provided by legumes (via biological nitrogen fixation from the atmosphere) as well as effective recycling of organic material such as crop residues and livestock manures.

- The primary use of preventive natural methods or mechanical methods to control weeds, diseases and pests.

- Non-use of chemical plant protection or synthetic fertilizers in order to protect the environment as a whole, including lakes, rivers, drinking water, etc.

- Planting of hedges and meadows to prevent soil erosion and nutrient loss.
The impact on biodiversity: organic farmers preserve and enhance biodiversity as much as they can, i.e. by means of multi-annual crop rotations or by employing mechanical and physical methods of soil cultivation in order to achieve optimum results for soil health structure. Organic cultivation methods provide for more native plants and animals and a higher concentration of micro-organisms and earthworms in the soil.

The impact on emissions: studies from different universities in Europe have shown that organic agriculture can produce low carbon emissions per hectare of land and consequently may contribute to reducing climate change - even more so if yields in organic farming can be improved. Possible contributing factors include:

- Carbon sequestration in organic matter because organic farming enhances the humus content in the soil.

- Reduced energy consumption through recycling of waste and by-products. facts about organic food Organic food is produced according to organic rules - all the way from farm to fork - and contributes to animal welfare, the environment and nature.

- No use of synthetic fertilizers produced in energy intensive processes.

- Retention of more native and general vegetation.

- Animal welfare. Animal welfare is an important feature of organic farming. The aim is to provide suitable conditions for natural behavior. This means that:

- Animals have access to grassland or outdoor areas.

- Animals have ample space in their housing units.

- Animals eat organic feed.

- For cows, the number of animals is balanced with the area of available land.

- Any use of substances to promote growth or the use of hormones or similar substances to control reproduction or for other purposes is prohibited. Synthetic allopathic veterinary medicinal products are not used for preventive treatment.

Non-GMO: use of genetically modified organisms (GMOs) and products produced from, or by, GMOs is not allowed.

Processing of organic food: only ingredients of natural origin are accepted when processing organic food. Only 53 of the 390 food additives approved in the EU are allowed in organic production. Synthetic flavorings, colorants, sweeteners, GMOs and irradiation are strictly prohibited.

Healthy food. Studies comparing the nutritional quality of organic versus conventional products indicate the presence of certain health promoting factors in organic products: 
- Organic dairy products and beef contain significantly higher levels of omega-3 fatty acid, linoleic acid and vitamin E.

- Organic fruit and vegetables have a higher level of antioxidants.

Food that matters:

- Organic food is authentic, high-quality and tasty.

- Organic labelling guarantees that all enterprises in the organic sector are

regularly inspected by authorities.

- Organic production provides food without synthetic flavorings, colorants

and sweeteners.

- Organic fruit and vegetables rarely contain traces of plant protection agents.

- Only a limited number of mostly natural additives are allowed in the processing of organic products.

- Genetically Modified Organisms (GMOs) are prohibited in organic farming and in the further processing of the products.

- Organic farming contributes to a high level of biodiversity and the preservation of species and natural habitats.

- Organic farming enhances soil life and natural soil fertility.

- As chemical plant protection is prohibited, organic farming contributes to the protection of the environment and can be practiced in drinking water protected areas.
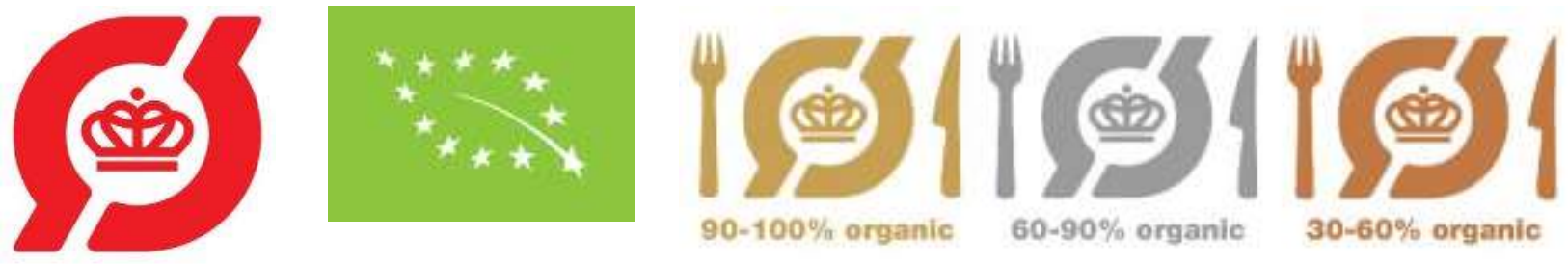

The widespread success of organic food products in Denmark was facilitated by the established Danish organic brand - a unique and state-certified ø-label certificate.

Denmark was the first in the world to introduce state control over organic products, which helped to increase consumer confidence in organic products. In 2020, the Danish label Red Organic celebrated its 30th anniversary.

A «farm-to-fork» philosophy of organic production takes into account nature, the environment and animal welfare as much as possible. The Danish red $\varnothing$ label as well as EU's green organic logo are guarantee of organic quality. [6].

Organic producers are inspected at least once a year. Checks are carried out in accordance with government regulations for organic production by
- Organic farming promotes animal welfare and provides good conditions for natural behavior. All organic animals have access to outdoor areas.

- Use of antibiotics and other drugs is severely restricted. Organic animals are raised without the use of hormones.

Regulations and control:

- Consumers across the world have great confidence in Danish organic food.

- Many rules and regulations govern all aspects of food production.

- Rules and regulations are monitored by meticulous government control.

- Focus on food safety and traceability.

- Organic control from farm to fork.

- Denmark was the first country in the world to establish government organic control in 1987.

- Yearly physical inspections of all organic farms and companies.

Organic food labels:

- Organic state-authorized label certifying that the product has been controlled by the Danish food authorities

- Mandatory label on all organic products sold in the EU.

- Danish certification system for large-scale kitchens (restaurants, school kitchens, catering etc.) indicating the percentage of organic raw material used in the kitchen. agencies of the Ministry of Food, Agriculture and Fisheries. Danish AgriFish checks primary products and Danish Veterinary and Food Authority checks food companies.

As noted in the source «Organic Denmark» «In 2009, The Ministry of Food, Agriculture and Fisheries introduced labels for the marketing of organic food in large-scale kitchens, restaurants, cafés, hospitals, schools and larger businesses. The Organic Cuisine Label is a free state-controlled labelling scheme for eateries. The Organic Cuisine Label shows the total share (in \%) of organic raw ingredients and beverages used in preparing the entire menu.

The Organic Cuisine Label is available in three versions: Gold (90-100\%), Silver (60-90\%) and Bronze (30-60\%)» [7]. 
Paving the way to success - Cooperation:

- Cooperation is the key driver behind organic sales growth in Denmark.

- Close collaboration on organic market development. level.

- Cooperation with all supermarkets at strategic

- Support to supermarkets in their expansion of organic product lines.

- Courses for small organic companies in their collaboration with retail and foodservice sectors.

- Advisory service on product development.

- Motivating consumers - $80 \%$ of Danes purchase organic products - more than $50 \%$ buy organic food every week.

Paving the way to success - policy development:

- Danish organic policy is a catalyst for organic innovation and growth.

- Involvement of many stakeholders in political policy development.

- Interaction between organic farms and food companies, consumers, the labour market and environmental and farm organizations in the creation of organic food policy in Denmark.

- Organic farming as a tool in broad national policies for the protection of nature, drinking water supply, climate, green growth and rural development.

- Push and pull strategy. "Pull" from the market "push" towards the farmers.

- Funding of organic development activities in the Fund for Organic Agriculture.

Paving the way to success - Organic research:
- The development of organic production is based on knowledge and innovation.

- Denmark has a strong research tradition in organic farming and food systems.

- Organic research supports development of new solutions and new knowledge throughout the supply chain.

- ICROFS - International Centre for Research in Organic Food Systems - coordinates the research.

- Stakeholder driven research - scientists, practitioners and advisers work together.

- Short pathway from new knowledge to practical implementation on farms and at companies.

- More than 20 years of targeted research has contributed to the success of organic production in Denmark.

General reasons for buying organic food:

- Safe, healthy and natural food - without synthetic flavorings, colorants and sweeteners. GMOs are prohibited.

- Good animal welfare - natural behavior with access to outdoor areas.

- Protection of the environment and drinking water - chemical pesticides are prohibited.

- Strong focus on sustainability.

- High consumer confidence in organic food due to state certification system.

- Food trends: local, healthy \& natural, and «easyto-make».

The organic market share is presented in figure 1 . The largest share of total sales of organic products was recorded in Denmark, in second place is Switzerland, in third place - Sweden [8].

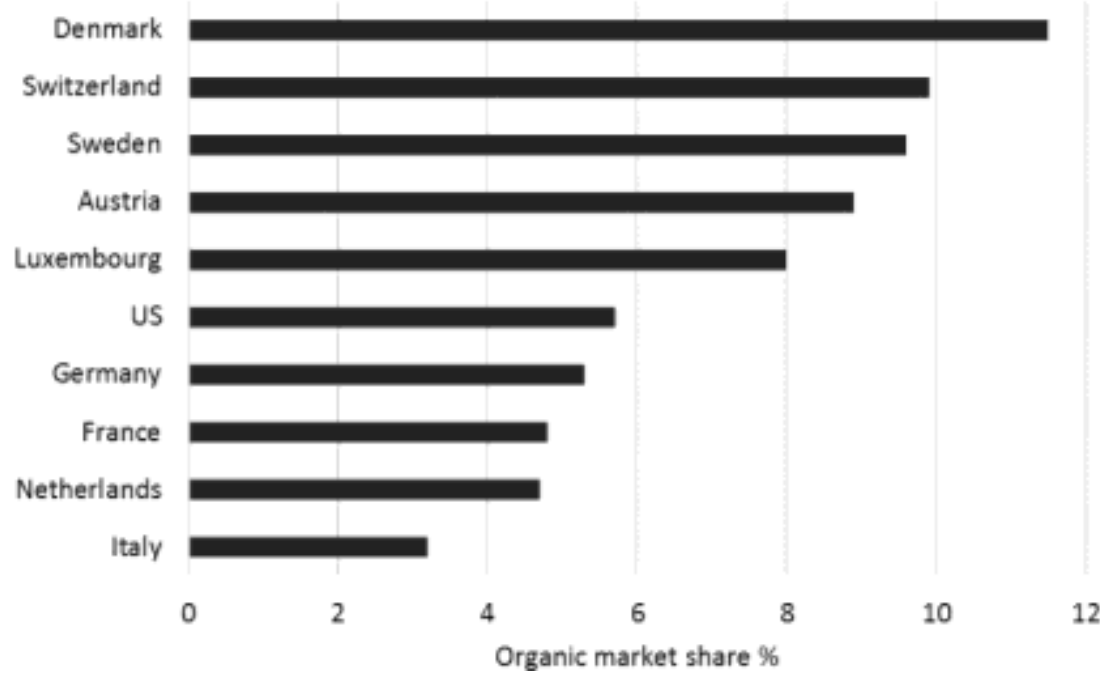

Figure. 1 - Organic market share (Source: FiBL 2019)

According to statistics GfK Consumer Scan the 10 most popular, organic products of Danish consumers anno 2019 are: natural yoghurt $(48.6 \%)$, carrots (45.2\%), oatmeal $(43.1 \%)$, bananas (36.5\%), cooking oil $(34.3 \%)$, milk $(32.3 \%)$, oranges $(29.9 \%)$, eggs (29.6\%), pasta (29.0\%), flour (29.0\%) [9].

Let us summarize the main positions regarding the organic production of individual industries. 
$1.10 \%$ of Danish farms are organic. They cultivate $11 \%$ of the agricultural land in Denmark. They produce good healthy raw materials with the utmost care for the environment, biodiversity and animal welfare.

All farmers receive 3-5 years of specialist agricultural training. Some organic farms are highly specialized - others produce a diverse range of product for direct sales. The specialized farmers focus on either production of vegetables, cattle, pigs or poultry. Focus is on developing and improving their products and yields through sound organic practice.

Organic Farming - plant production. Chemical plant protection and synthetic fertilizers are not allowed. Nutrients provided by legumes and recycling of organic materials as crop residues and livestock manures. Enhances soil life and natural soil fertility. Contributes to a high level of biodiversity and the preservation of species and natural habitats. Contributes to the protection of the environment. The yield from organic fields is typically $10-30 \%$ lower compared to conventional plant production.

2. Animal welfare in organic milk and beef production. Good conditions for natural behavior. Access to pasture from 15th April to 1th November. Ample space in their housing units. The winter housing system must ensure freedom of movement. Feed must be $100 \%$ organic with a lot of roughage. Use of antibiotics and other drugs is severely restricted. If treated with veterinary medicine - the withdrawal period is twice as long as the non-organic withdrawal period. Cows are raised without the use of hormones.

3. Animal welfare in pig production. Good conditions for natural behavior. Access to grassland or outdoor areas. Ample space in their housing units. No tail docking. In Denmark, sows farrow in an outdoor hut with access to pasture. $100 \%$ organic feed in Denmark. Plenty of roughage, which benefits the pigs' digestion. Use of antibiotics and other drugs is severely restricted. If treated with veterinary medicine - the withdrawal period is twice as long as the non-organic withdrawal period. Organic pigs are raised without the use of hormones.

4. Animal welfare in organic egg production. Good conditions for natural behavior. Access to outdoor areas. Outdoor areas have to be covered with vegetation. The minimum outdoor stocking density is $4 \mathrm{~m} 2 /$ hen. Indoor stocking density is maximum 6 hens $/ \mathrm{m} 2$. The building must have natural day-light and a resting period of at least 8 hours is required. Organic feed with a lot of roughage. Access to perches and to areas for dust bathing and scratching. Beak trimming is not allowed. Use of antibiotics and other drugs is severely restricted.

5. Animal welfare in organic poultry Production. Slow-growing breeds. Good conditions for natural behavior. Access to outdoor areas. Outdoor areas have to be covered with vegetation. The minimum outdoor stocking density is $4 \mathrm{~m} 2 /$ boiler Indoor stocking density is maximum 10 boilers $/ \mathrm{m} 2$. The building must have natural day-light and a resting period of at least 8 hours is required. Access to areas for dust bathing and scratching. Organic feed with a lot of roughage. Beak trimming is not allowed. Use of antibiotics and other drugs is severely restricted.

Danish companies export to near markets such as Germany, Sweden and France and to distant markets in Asia, the Middle East and US. The three largest export markets in 2017 were Germany, Sweden and China respectively. Denmark has many livestock production companies - large and small - that are committed to organic production and to export. It is therefore not surprising that the largest export products are dairy products - fresh milk, cheese, butter and powdered milk - and pork. Danish companies are also well positioned to supply eggs and poultry as well as vegetable products such as feedstuffs, vegetables, groceries and drinks.

Conclusion. Organic agriculture is knowledge intensive and should be adapted to local conditions and the farmers' situation. Thus, there is need for further development in line with the principles of organic agriculture and there is a need for improved knowledge transfer systems which acknowledges traditional as well as scientific knowledge

The Danish model of the organic path of development is of great importance for the perception of the population of the world around the principles of bioethics in their daily lives. This model has proven its effectiveness for more than 30 years. The difficult period of human development that the whole world is going through encourages the revision of traditional food production and the transition to organic farming. This path, of course, is not easy and requires great effort and will to implement such plans. The health and life of all living things on the planet will be the key to large-scale changes in the minds and actions of people around the world.

\section{Список використаних джерел:}

1. Codex Alimentarius Commission, 1999. URL: http://www.fao.org/input/download/report/250/nf00_01e.pdf

2. What is organic agriculture? URL: http://www.fao.org/organicag/oa-faq/oa-faq1/es/

3. Principles of organic agriculture. URL: https://www.ifoam.bio/why-organic/shaping-agriculture/four-principles-organic

4. Global organic food market nears $€ 100$ billion. URL: https://www.euractiv.com/section/agriculture-food/news/global-organicfood-market-nears-100-billion/ 
5. The organic way - the Danish model. URL: https://www.organicdenmark.com/facts-figures-about-danish-organics

6. Organic food labels. URL: https://www.organicdenmark.com/the-danish-organic-label

7. What is the Organic Cuisine Label? URL: https://www.oekologisk-spisemaerke.dk

8. Organic market share. URL: https://statistics.fibl.org/

9. Facts and figures about Danish Organics - Organic Denmark. URL: https://www.organicdenmark.com/facts-figures-aboutdanish-organics

10. World leading organic nation - Organic Denmark. URL: https://www.organicdenmark.com/world-leading-organic-nation

\section{О. Клаусен, Л.С. Патрева. Датская модель органического сельского хозяйства}

В статье рассмотрены основные элементы датской модели органического сельского хозяйства. Раскрыты причины выбора Данией такого пути развития. Показаны успехи фермерских хозяйств, которые основаны на органическом производстве. Продемонстрирована актуальность перехода всего сельского хозяйства на органическое производство, как одного из биоэтических составляющих развития общества в современном мире и осуществления масштабных сдвигов в сознании и действиях людей всех стран мира.

Ключевые слова: органическое сельское хозяйство, Датская модель, регламент, контроль.

\section{О. Клаусен, Л.С. Патрєва. Данська модель органічного сільського господарства}

У статті розглянуто основні елементи данської моделі органічного сільського господарства, розкрито причини вибору Данією такого шляху розвитку. Показано успіхи фермерських господарств, які засновані на органічному виробництві. Продемонстровано актуальність переходу всього сільського господарства на органічне виробництво, як одного з біоетічних складових розвитку суспільства в сучасному світі і здійснення масштабних зрушень у свідомості і діях людей всіх краӥн світу.

Ключові слова: органічне сільське господарство, Данська модель, регламент, контроль. 